\title{
Syrian University Students in Turkish \\ Higher Education: Immediate \\ Vulnerabilities, Future Challenges for the \\ European Higher Education Area
}

\author{
Armağan Erdoğan and M. Murat Erdoğan
}

\section{Introduction}

\begin{abstract}
"Making our systems more inclusive is an essential aim for the EHEA [European Higher Education Area] as our populations become more and more diversified, also due to immigration and demographic changes." (Yerevan Communiqué 2015)

"We recognize that further effort is required to strengthen the social dimension of higher education. In order to meet our commitment that the student body entering and graduating from European higher education institutions should reflect the diversity of Europe's populations, we will improve access and completion by under-represented and vulnerable groups". (Paris Communiqué 2018)
\end{abstract}

Achieving inclusive higher education systems has been one of the priorities of the Bologna Process confirmed in the Ministerial Communiqués since its beginning (Zgaga 2015). The term social dimension, defined as "the student body entering, participating in and completing higher education at all levels should reflect the diversity of our populations", has been one of the targets on the agenda since then (London Communiqué 2007). Nevertheless, it is one of the actions that has not been improved and clearly measured so far. To recall the statement in the Leuven and Louvain-laNeuve Communiqué in 2009, it calls for setting measurable targets for increasing participation of underrepresented groups by the end of the next decade. Paying particular attention to underrepresented groups was repeated in the following Ministerial Declarations/Communiqués in Budapest-Vienna in 2010 and in Bucharest in 2012. When new challenges appeared at the borders of EU after the Syrian crisis, a clear reference to this immigration was mentioned in the Yerevan Communiqué in 2015 as can be seen in the above quotation. Three years later, in the Paris Communiqué

\footnotetext{
A. Erdoğan ( $\varangle)$

Beykoz University, Istanbul, Turkey

e-mail: armagan.erdogan2012@gmail.com

M. M. Erdoğan

Turkish-German University, Istanbul, Turkey

e-mail: merdogan1103@gmail.com

(C) The Author(s) 2020

A. Curaj et al. (eds.), European Higher Education Area: Challenges for a New Decade, https://doi.org/10.1007/978-3-030-56316-5_16
} 
in 2018, the critical role of the social dimension of higher education was repeated without mentioning refugees or even migrants in the text. Completing two decades and creating unique and successful regional higher education cooperation with borders reaching far beyond the European Union, the European Higher Education Area is now facing its future with new challenges, such as the refugee influx. Considering that Ministerial statements give new directions for the new targets, policies and practices for higher education in the member states, a more inclusive approach within the EHEA is needed. Contextual and geographical diversity can make the EHEA more inclusive (Zgaga 2015; Jungblut and Pietkiewicz 2017). For this reason, we hope that this paper, examining Turkey's inclusive policies and practices developed and implemented for the refugee students since 2011, will contribute to the future of the EHEA. Before analysing the findings of our research, Elite Dialogue II, conducted in 2019 and funded by Hopes-MADAD, a brief contextual analysis on refugees in higher education in Europe and on a global scale will be useful to set the ground.

In this tumultuous period of the new global challenges, higher education is a key component to facilitate the personal empowerment, social cohesion, and economic welfare of the vulnerable persons or groups (Cremonini 2016; de Wit and Altbach 2016; Stevenson and Baker 2018; UNHCR 2019b). The social responsibility of higher education needs to respond to the current and future challenges of societies. Migration is one of the most important challenges of our age in the global context. People move from their birthplace elsewhere to obtain better living conditions, better employment, and educational opportunities (UNESCO 2017). It is happening more intensely and faster than ever before in world history. However, it must be emphasized that forced migration occurs due to crises and in the form of influx in emergent situations (Piguet 2018; Bloch and Dona 2019). Therefore, forced migration and its reflections on higher education is a situation that needs to be addressed in a very different way. In many parts of the world, large masses of people are forced to leave their hometowns and places of living because of war, hunger, violence, the danger of death, or other threats. The situation for these people differs legally, politically, socially, economically, and psychologically from those who migrate voluntarily. Furthermore, $63 \%$ of voluntary migrants live in developed countries and are regarded as a positive influence on the economy, whereas $80 \%$ of forcibly displaced people find shelter in neighbouring countries which are not developed (International Organization for Migration (IOM) 2020). Starting from the most basic needs, they have different disadvantages, vulnerabilities, fragilities, and sensitivities. The majority of this group consists of young people and children, which puts the need for education on top of the priority list. Higher education plays a crucial role both for individual, social and economic capacity and the empowerment of vulnerable groups and refugees who have lost their stable conditions (Streitwieser et al. 2016).

Article 26 of the Universal Declaration of Human Rights puts forth a common standard that higher education shall be equally accessible to all on the basis of merit (UN 1948). Similarly, the 1951 Geneva Refugee Convention is the milestone international agreement for defining the status of refugees. Article 22 of the Convention on Public Education clearly states the importance of education for refugee populations. "The Contracting States shall accord to refugees the same treatment as is 
accorded to nationals with respect to elementary education. The Contracting States shall accord to refugees treatment as favorable as possible, and, in any event, not less favorable than that accorded to aliens generally in the same circumstances, with respect to education other than elementary education and, in particular, as regards access to studies, the recognition offoreign school certificates, diplomas and degrees, the remission of fees and charges and the award of scholarships" (UNHCR 1951). Although the Convention does not clearly name higher education, it is still one of the fundamental references facilitating higher education policies for refugee populations.

Unfortunately, although international agreements are in place to guarantee the education rights of displaced people, UNHCR data show that refugees' access to higher education remains only 3\% (UNHCR 2019b). This ratio shows that young people exposed to forced migration face extra barriers in accessing higher education that cannot be easily eliminated. Therefore, responses to this emergency need to be multidimensional from immediate action to mid- and long-term policies for integration, cohesion, and inclusion. Higher education has been one of the areas that new policies have developed according to need since the Syrian crisis in 2011. Higher education institutions, governments, international associations, UN agencies, and private funders have invested in facilitating access for refugees. In the 2015 Sustainable Development Goals and Targets: "By 2030, ensure equal access for all women and men to affordable and quality technical, vocational and tertiary education, including university" (Goal 4.3) is in line with the "no one is left behind" commitment of the United Nations' Agenda for Sustainable Development (UN 2015). In 2016, in the New York Declaration for Refugees and Migrants, all Member States of the UN agreed that protecting those who are forced to flee and supporting the countries that shelter them are shared international responsibilities that must be borne more equitably and predictably (UN 2016). In 2018, the Global Compact on Refugees (GCR) defined four key objectives to "ease the pressures on host countries, to enhance refugee self-reliance, to expand access to third-country solutions, to support conditions in countries of origin for return in safety and dignity" (UNHCR 2018). These new policies were developed around global acceptance that education is a right, and all measures ought to be taken to preserve human dignity. Host countries take responsibility for facilitating their participation and taking measures for a holistic integration framework, but the rest of the world has a responsibility to share the burden. In December 2019, the first Global Refugee Forum took place in Geneva, aiming to create a framework for global support for the education of refugees and host communities, complimenting both GCR and SDGs "to ensure inclusive and equitable quality education and promote lifelong learning opportunities for all" by 2030 (UNHCR 2019c). However, global figures show that only 3\% of refugees (which was only $1 \%$ in 2016) have access to higher education in the world. UNHCR plans to ensure that $15 \%$ of refugees have access to tertiary learning by 2030 .

The refugee crisis became more visible after more than a million refugees crossed the borders into the EU in 2015, and in 20161.2 million people sought shelter in the EU. Each country accepted different numbers and implemented different approaches for integrating these newcomers from outside the EU. While the "majority of countries have no specific policy approach to integrate asylum seekers and refugees into 
higher education", large scale measures in addition to linguistic, financial, and academic support were needed (European Commission/EACEA/Eurydice 2019). Collective measures were taken by the European Union (EU), the European Higher Education Area (EHEA), the European Universities Association (EUA) and other institutions or NGOs for those who were about to start post-secondary education or who dropped out of their higher education. Similarly, the EU initiated new programs, funds, and strategies in its actions for the refugees both within and outside of Europe. The EUA developed some tools to support universities and refugees as well as to support peer-learning collaboration between them. In line with the Lisbon Recognition Convention, the European Qualifications Passport for Refugees was developed to "provide reliable information for integration and progression towards employment and admission to further studies" even for those without any documents (Council of Europe 2019). The Bologna Process values and tools, such as social dimension and recognition of prior learning as well as the Lisbon Recognition Convention, have been principal keys for new action in Europe. Yet, peer learning, experience sharing, and research on responses from non-EU countries seem to be neglected or not fully disseminated in this process. This paper aims to fill this gap by exploring the experience of Turkey in integrating large numbers of Syrian students into higher education.

According to 2019 UNHCR data, 70.8 million people have been forcibly displaced on the global scale due to war, conflicts, violence, and persecution. Around 25.9 million of them are categorized as refugees. The Syrian civil war created a massive influx, and 6.7 million Syrians have been forcibly displaced outside of their country. This is true for Syrian refugees as a majority are being hosted by neighbouring countries, such as Turkey (64.3\%), Lebanon (16.4\%), Jordan (11.8\%), and Iraq $(4.4 \%)$ with relatively low numbers able to reach Europe (1.4 million) (UNHCR 2019a). Turkey hosts the highest number of refugees with 4.1 million (3.5 million Syrians and 500,000 people from Afghanistan, Iraq, Iran, and Pakistan). Moreover, these numbers are increasing on a daily basis due to newborn babies and newcomers due to ongoing conflicts in the region.

Turkey's response to the refugee influx from Syria has been unique from many perspectives. Having the longest borders with Syria as well as the political will to help people fleeing from the war created a rapid and massive influx starting in 2011. Two crucial aspects describe the process and frame the current status in Turkey. One is the legal status of the Syrian immigrants, and the other is the open-door policy Turkey implemented at its southeast borders while closing the western borders after the crises started. To start with the legal status, although in this paper and elsewhere "refugee" or "asylum-seeker" are used to define the Syrian people in Turkey, their legal status is, in fact, "temporary protection" a form of international protection. The reason is the "geographical reservation" Turkey put in the Geneva Convention to prevent providing "refugee" status to non-European asylum-seekers (Erdogan and 
Fig. 1 Top refugee hosting countries Source (UNHCR 2019a)

\section{Top refugee-hosting countries}

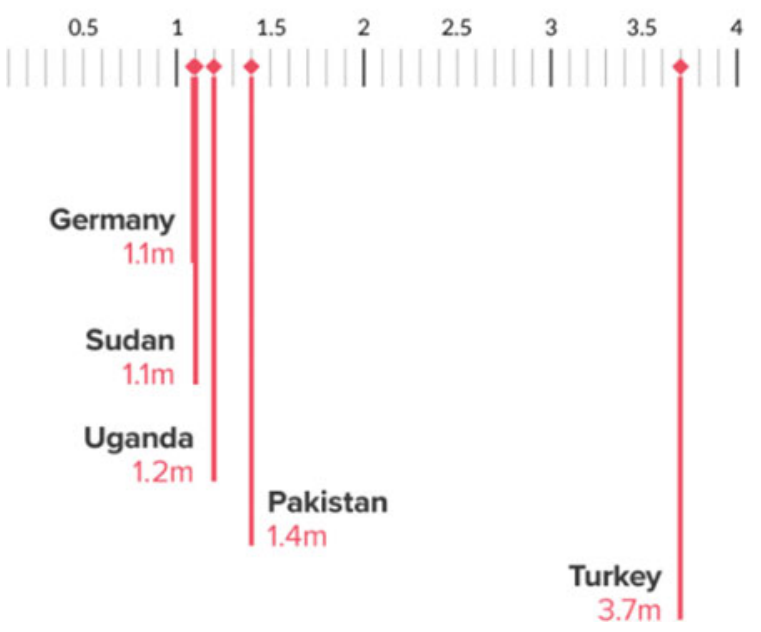

Erdogan 2019). ${ }^{1}$ The Law on the Foreigners and International Protection (2013) and the secondary legislation, notably the Temporary Protection Regulation (2014) also adopted the principle of geographical restriction. From the very beginning of the process, this massive influx was expected not to remain long but to return home after the war ended (Kirişci 2014; Erdogan 2018a,b). Another crucial notion is "temporariness" arising from their legal status, which hindered the long-term policies (Erdogan 2018b) (Figs. 1 and 2).

The second aspect is the demographics in terms of magnitude and profile, which also affect the planning of the policies and services. Significantly, the number of foreigners under international protection in Turkey was merely 58 thousand in 2011 , prior to the outbreak of the Syrian crisis, whereas the numbers are currently over 4 million coming from Syria and other countries. These figures dramatically constitute more than $5 \%$ of the 82 million population in Turkey. The process started as an emergency to meet the very basic needs of the thousands of people at the borders, evolved to seeing them as "guests", and finally became an integration and social cohesion process after nine years. Due to the magnitude and speed of the influx, a somewhat inevitable flexible settlement policy was applied. Syrian refugees settled in the cities of their choice; currently, only very little numbers, $1.8 \%$, are in the camps (DGMM 2020). Another significant demographic indicator is the education profile of Syrians hosted in Turkey. According to self-reported registration data, $33.3 \%$ of the Syrians stated that they are illiterate, while the rate of literate yet non-

\footnotetext{
${ }^{1}$ International obligations of Turkey in terms of asylum-seekers and refugees are determined under the "1951 Geneva Convention" and the "1967 Protocol relating to the Legal Status of Refugees". As a party to the Geneva Convention, Turkey declared that it would impose a "geographical restriction" exception in the contract with a declaration dated 29 August 1961, i.e. it would not accept incomers from outside Europe for whichever reason as "refugees".
} 


\section{DISTRIBUTION OF SYRIAN REFUGEES IN THE SCOPE OF TEMPORARY PROTECTION BY YEAR}

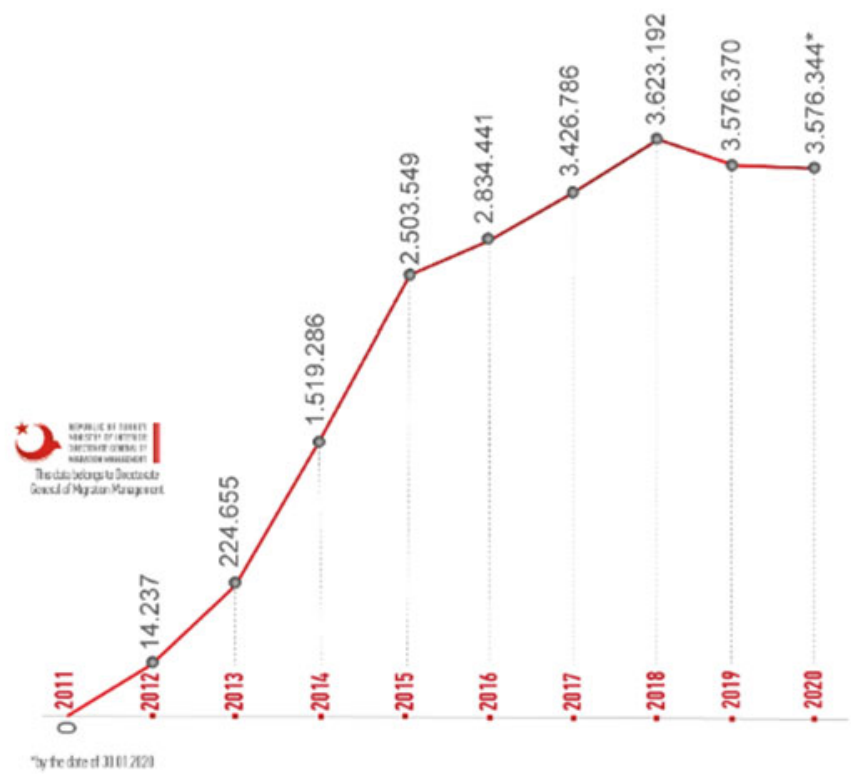

Fig. 2 Numbers of Syrians under temporary protection Source (Directorate General of Migration Management (DGMM) 2020)

graduate Syrians is 13\% (Ministry of Development 2015). According to the data of the DGMM and the Ministry of National Education (MoNE), the number of Syrian children at the compulsory schooling age group in Turkey, i.e. between the ages 5-17, is $1,234,000$. At present, $61.41 \%$ of them have been enrolled in Turkish schools. More than $1,694,000$ Syrians, which makes $46.4 \%$ of their population in Turkey are under 18, and 778,044 people are between 15-24 (DGMM 2020). Gender imbalance is another demographic indicator affecting education policies, as the male population $(54.1 \%)$ is quite a bit higher than the female population (45.8\%); when it comes to accessing education, the female population is highly disadvantaged. The above demographic scale of Syrians in Turkey underlines education as a crucial component of the integration policies to be tackled not to create lost generations. 
Fig. 3 Higher education institutions in Turkey Source Data compiled from CoHE statistics, 2019

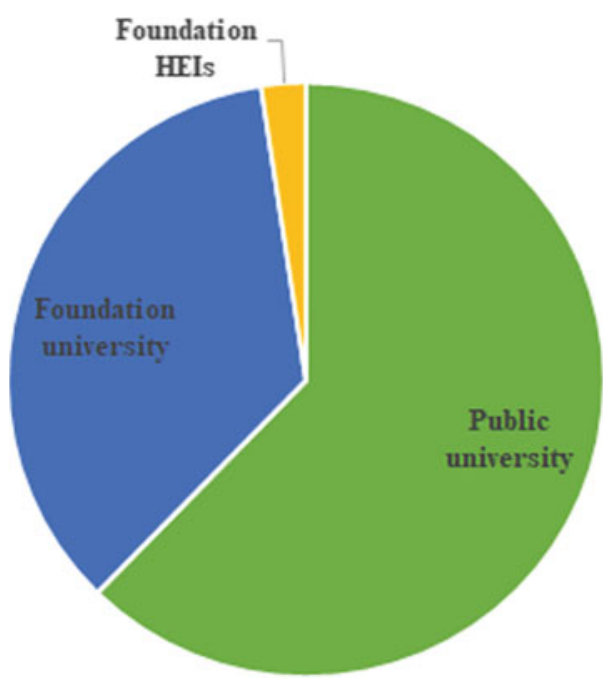

\section{Two Syrian Students' Access to Higher Education in Turkey}

Although Syrians do not hold the official/legal refugee status, they can benefit from all public services in Turkey, including health and education, free of charge. Therefore, Turkey's inclusive policy providing higher education to Syrian refugees can be acknowledged as a good example for other EHEA countries. Starting with some brief information about the current status of higher education in Turkey will be useful in understanding the policies developed for Syrian students in higher education. In Turkey, the Council of Higher Education (CoHE) has been the responsible authority to coordinate, plan, supervise, and govern higher education since 1981. There are 207 higher education institutions, and more than 7.7 million students in the three-cycle system (Figs. 3 and 4).

Access to higher education for Turkish students is highly competitive and is tracked through a central exam applied annually. Demographic indicators, as well as the structural difficulties, create challenges in planning higher education. To give an example, 2,381,412 students took the exam in 2019, and 857,240 (36\%) were placed in a program (CoHE 2019). In spite of the enlargement of the system with the new higher education institutions established in the last decade, supply and demand imbalance remains one of the main challenges in Turkish higher education system. The youth unemployment rate (15-24 age) has reached $24.5 \%$, therefore accessing top universities became more important both for prospective students and their parents. Access of the international students is organized individually by HEIs, according to the related regulation prepared by the CoHE. 


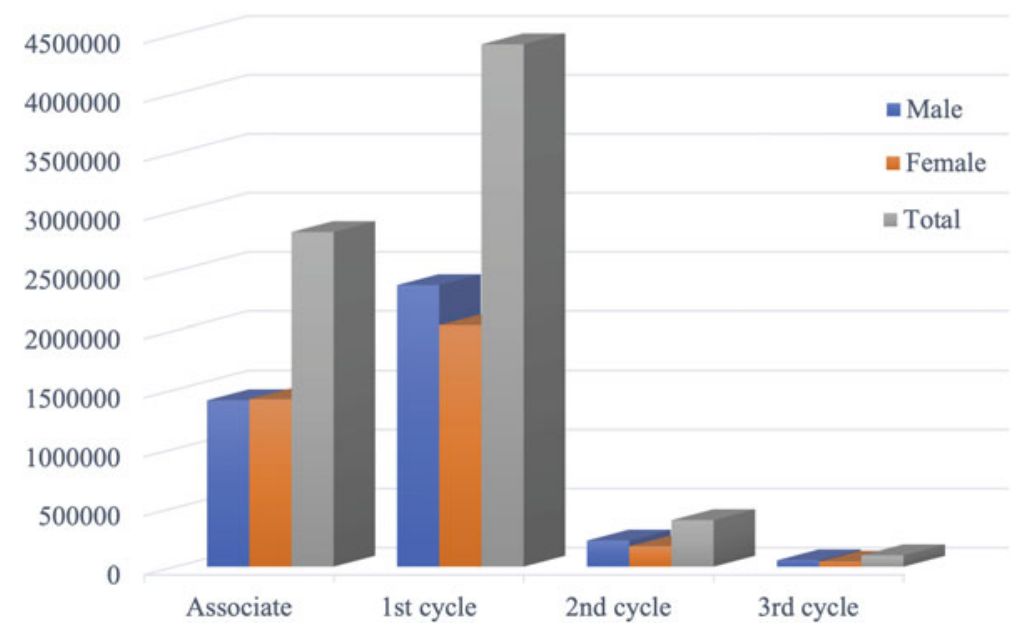

Fig. 4 Numbers of Turkish students (2018-2019)

Source Data compiled from CoHE statistics, 2019

In response to refugee youth in need of access to higher education, the CoHE implemented flexible new tools and policies immediately after the influx in 2011 and has revised the regulations each year according to new needs (Y1ld1z 2019).

These tools can be listed as follows:

1. Special Student status: On September 3rd, 2012, the CoHE approved a new regulation for the 2012-2013 academic year for Syrian students and Turkish citizens who had to interrupt their education while studying in Syria. According to this regulation, seven state universities, ${ }^{2}$ mostly close to the border region, were given the opportunity to accept Syrian students as "special students". This status did not allow students to receive a degree but facilitated those without any documents to take courses which may be transferred in due course (Habertürk Newspaper 2014; Erdogan 2018a, 87; Y1ld1z 2019, 81). In order to include students without documents, the statements of students were taken into account.

2. Transferring the credits: In the following year, a new regulation was created in which, before the 2013-2014 academic year, those who had started associate, undergraduate and graduate programs (except in Medicine and Dentistry) in Syria and Egypt could transfer to higher education institutions in Turkey:

- Students are able to transfer to the first year and the final year if they have all the necessary documents for the transfer,

- Higher education institutions should ensure that the transfer applications do not exceed 10\% of the OSYS (Student Selection and Placement System) quota of the department applied to by the students in the relevant year,

\footnotetext{
${ }^{2}$ These Universities are Gaziantep, Kilis 7 Aral $\iota$, Harran (Ş anl $\iota$ urfa), Mustafa Kemal (Hatay), Osmaniye Korkut Ata, Çukurova (Adana) and Mersin.
} 
- It was decided that the students who did not have the required documents for transfer could take courses in the seven mentioned universities as "special students", and those who provided their documents could transfer horizontally (CoHE 2014).

3. Opening Arabic programs: On November 9th, 2015, "It is decided that universities (above mentioned seven universities plus Kahramanmaraş Sütçü İmam University) can open programs in Turkish and/or foreign language with the approval of the Executive Board of Higher Education for the students coming from Syria" (Milliyet Newspaper 2015). Thus, it was made possible to open programs in Arabic or other languages in accordance with the needs and suitability of Syrian students in these universities.

4. Tuition fees removed: Tuition fees have been determined by the Council of Ministers annually; and for Syrian students in the public universities are paid for by the Turks Abroad and Relative Communities Presidency (Official Gazette 2014). It allowed Syrian students to be exempted from tuition fees as another tool to facilitate their access to higher education.

5. Financial support: The Presidency for Turks Abroad and Related Communities (YTB), a public institution provides and coordinates the financial support allocated by different international organizations, such as UNHCR, DAFI, and NGOs.

Currently, the following four requirements are asked from the Syrian students to get access to university: identification number issued for the Syrians under temporary protection by DGMM; proof of having completed Grade 12; results of the Foreign Students Examination (YOS) administered by each university, and proficiency for language test. Students who continued their university studies in Syria but could not complete due to war can apply to transfer their credits to any Turkish university.

Syrian students' access to higher education in Turkey has remarkably increased each year. The number of Syrian students in around 100 public and 50 foundation universities in Turkey was 14,747 in the 2016-2017 academic year; 20,701 in 2017-2017 and reached 27,034 in 2018-2019. According to unpublished statistics in October 2019, following the similar trend of the previous years, the number of Syrian students increased to 33,000 students. ${ }^{3}$ They are enrolled in 153 different Turkish universities, $46.4 \%$ of these students are registered at 10 universities and $65 \%$ in 11 cities in the region. While Gaziantep University based in the border city hosts $11.2 \%$ of all Syrian university students, Istanbul as a city hosts $21.8 \%$ of them (CoHE 2019) (Fig. 5).

The inclusive and proactive response of Turkey to integrate Syrian youth into higher education can be regarded as a success story when taking into account the number of students and the various tools developed for their access. Nevertheless, there are also difficulties, challenges, and areas for improvement. One of the areas for improvement is the lack of data shared about their academic fields, backgrounds, success rates, life conditions, integration with students and other members of Turkish

\footnotetext{
${ }^{3}$ According to a presentation made by the CoHE representative at UNHCR Higher Education Working Group.
} 


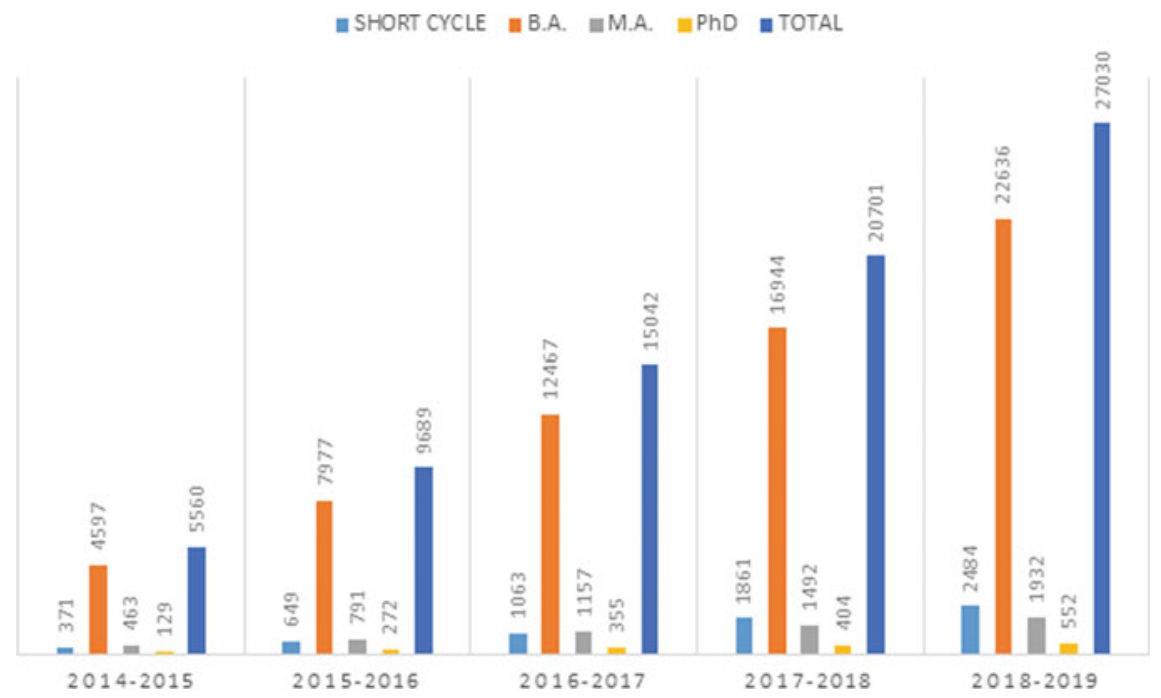

Fig. 5 Increase of numbers of Syrian university students in Turkey Source (Ministry of National Education, Directorate General Life Long Learning Report 2020)

society, and future perspectives. Therefore, Elite Dialogue Projects (ED I and ED II) aimed to make modest contributions to overcome the lack of data and academic discussions in this topic.

\section{Three Elite Dialogue Project Findings}

What is the experience of Turkey as the country hosting the largest refugee population and also with the largest refugee student population in higher education? Based on the findings of our Elite Dialogue projects in 2017 and 2019, we can share the good practices, experiences, and challenges of Syrian students in Turkish higher education. ${ }^{4}$ The main objective of the ED projects is to draw attention to the shaping of integration policies based on the views of refugees and to highlight the critical role of qualified groups in the integration process. The Elite Dialogue-I (ED-I) project was carried out in 2017, and the Elite Dialogue II (ED-II) project "Dialogue with Syrian Refugees in Turkey through Syrian Academics and Postgraduate Students" funded by EU Hopes-MADAD was carried out from January 2018 to March 2019. In this paper, the findings of the ED-II student survey will be analysed in comparison to the results of ED-I whenever appropriate.

\footnotetext{
${ }^{4}$ The findings of a part of ED-I student survey was published by the authors in 2018 as "Access, Qualifications and Social Dimension of Syrian Refugee Students in Turkish Higher Education", in The European Higher Education Area: The Impact of Past and Future Policies, eds. Curaj, Adrian, Deca, Ligia, Pricopie, Remus, Springer.
} 


\subsection{Methodology of Research}

The research was carried out using quantitative and qualitative research methods on three main axes: examining reports and official documents, conducting four thematic workshops in different cities with Syrian academics working in Turkish universities, and a survey with Syrian students.

The research had two main aims:

1. To present the conditions, challenges, and expectations of the Syrian university students and academics among the Syrian refugees (under temporary protection status) in Turkey.

2. To make policy recommendations for the future through the opinions of the qualified groups among Syrian refugees for comprehensive and long-term policies, starting from the idea that the tendency of Syrians to remain in Turkey has increased.

ED-I and II Surveys tried to have a representative sample for the research. The content of the questionnaire to be applied to students was inspired by EUROSTUDENT projects, aiming to determine the socioeconomic profiles and academic achievements of university students in the European Higher Education Area. ${ }^{5}$ Therefore, the results may contribute to the future implications for the EHEA.

The questionnaire, which was based on four topics (post-war vulnerabilities, family background, academic qualifications, socioeconomic conditions) in the ED-I, was enlarged for the ED-II and designed to obtain data regarding the following seven topics: Basic Demographics, Educational Background; Immigration Background: Support Network, Diaspora, Duration of Stay, Secondary Education; Satisfaction with Different Aspects of Education in Turkey; Vulnerabilities: Trauma, Housing, Income; Livelihoods: Scholarships/Work; Economic Integration Attitudes/Future Prospects; Social Integration Attitudes: Prejudice, Social Distance, Institutional Trust; and Policy Recommendations. The majority of the questions stayed the same though some changes and additions were made as a result of our experience in the ED-I. For this reason, it is possible to make comparisons for the same questions in both rounds of the surveys. Following the preparation of the questionnaire, it was tested in a pilot scheme. A mixed field model was applied. The questionnaires were prepared on paper and given to university students in the provinces visited for the workshop, and they were also invited to participate online with "SurveyMonkey" by using students' communication groups and the snowball survey method. In the sample selection, quota-based interventions were made considering the real distribution of the participants, according to the cities and universities. As a result, a highly representative sample was obtained. The survey allowed for the collection of valuable data on Syrian students and the observation of trends. However, although a part of the survey was delivered to the students in print, it should be mentioned that it was generally carried out via "SurveyMonkey". The error rate of the survey is estimated to be about

\footnotetext{
${ }^{5}$ For Euro-student projects: https://www.eurostudent.eu.
} 
5\%. Therefore, our evaluations and analysis should be taken into consideration with these limitations.

In order to ensure that the sample is representative, a stratified quota sampling based on the number of Syrian students in different provinces was adopted. Furthermore, throughout the field study period, the sample was regularly crosschecked against the actual distribution of students across the different provinces where the universities are located. Data for this was obtained from the Higher Education Council data, and a high level of overlap is targeted. To this end, where the sample falls short of the actual share of the Syrian students, academics, students, and NGOs were mobilized to assist with the offline interventions, and the project's social media account was promoted in these target provinces using online interventions.

\subsection{Vulnerabilities, and Challenges of Syrian Students}

In Turkey, 27,034 Syrian students are enrolled in 153 universities out of 207 universities in total. A total of 1,058 students in 46 cities participated in ED II survey, and 747 students answered more than $70 \%$ of the questionnaire. ${ }^{6}$ The results of the 747 students who completed the whole questionnaire have been evaluated in our finding. Different from the rates of Turkish students, which is $52.5 \%$ male and $47.5 \%$ female; the gender imbalance rate is high in Syrian university students. The gender distribution of the respondents is similar to the Syrian student population in the universities; 562 respondents (75\%) were male, and 185 (25\%) were female. The actual rates of Syrian students in Turkish universities are 17,096 (63.23\%) male and 9,938 $(36.76 \%)$ female. The research sample also tried to reach students from all cycles: about $3 \%$ were enrolled in short cycle programs, $88 \%$ of the students were undergraduate, and the remaining $9 \%$ were pursuing graduate studies either in masters or Ph.D. programs. This is consistent with the Syrian student distribution in Turkish universities (92\% undergraduate and $8 \%$ postgraduate).

In the ED-I, those who stated that they were enrolled at a higher education institution before coming to Turkey was $45.47 \%$ (226 students out of 497). In the ED-II, this rate increased to $48 \%$ (507 students) of the respondents that participated in our survey. Of these students with past university enrolment, $12.2 \%$ (62 students) attended for one year, $16.3 \%$ (83 students) finished two years, $13.2 \%$ (67 students) completed three years, and $15.5 \%$ (79 students) completed four years of studies in Syria. Among these students, $70 \%$ indicated that they could not transfer any of their credits, while $20 \%$ said they partially transferred their credits, and $10 \%$ stated that they fully transferred their credits. These rates need to be investigated further in order to understand the experiences and difficulties of the students during the transfer period. Since the process is done without official documents, reliability and validity become crucial for the recognition and participation to the programs.

\footnotetext{
${ }^{6}$ The number of surveys conducted in the ED-I study was 470 students in 36 provinces.
} 
Table 1 Paths to access higher education

\begin{tabular}{l|l|l}
\hline Path & Number of respondents & $\%$ \\
\hline $\begin{array}{l}\text { Direct transfer from my HE } \\
\text { Institution in Syria }\end{array}$ & 92 & 12.43 \\
\hline Applied to the university quota & 391 & 53.11 \\
\hline Took the YÖS exam & 211 & 28.65 \\
\hline Entered as a special student & 34 & 4.59 \\
\hline Other & 47 & 15.41 \\
\hline Total & 740 & \\
\hline
\end{tabular}

Source ED II questionnaire

One of the most important indicators is to discover the routes they followed in their admission process. This is a new question for the ED-II. Significantly, 53\% applied for the international student quotas offered by universities, which have been increased after the mass influx of Syrian refugees in Turkey, following a regulation implemented by the Council of Higher Education. This result is critical in terms of quality, as the students were accepted without taking the YÖS exam. Almost 29\% took the more competitive Foreign Student Exam (YÖS) prepared by the universities they applied to, $12 \%$ directly transferred from their institution in Syria, and about $5 \%$ started as "special students" again as a result of a tool developed by the CoHE and continued to the full degree program. This data clearly indicates the diversity of access procedures implemented by the Syrian refugees and the positive impact of the facilitating regulations centrally planned by the CoHE and implemented by the universities.

Regarding the distribution of their chosen field of study, about $40 \%$ are enrolled in various engineering programs with civil and computer engineering being the most popular departments within this field. About 30\% are enrolled in administrative and social sciences, including political science and international relations, and $18 \%$ are enrolled in health sciences, including medicine, dentistry, and pharmaceutics departments. Significantly, comparing the results of the ED-I and II, participants studying both engineering and health sciences seems to have increased, which can also be interpreted as a positive sign; since it will be useful for the Syrian students if they return Syria to reconstruct their country. On the other hand, the results have created a discussion amongst the Turkish public that Syrian students are taking the place of some Turkish students, as these fields are highly competitive among Turkish students who have to take the central exam to get access to universities (Table 1).

With regard to marital status, about $20 \%$ of the respondents indicated that they were married while the remainder is single. This is a rather high percentage compared to Turkish university students and may result in more responsibilities for running a household with a potential impact on their success in higher education.

In order to note any problems encountered while they were trying to access higher education, they were asked a specific question regarding problems/challenges accessing HE. The following table not only illustrates the distribution of different challenges 
Table 2 Important problems/challenges accessing to HE

\begin{tabular}{l|l|l}
\hline Category & ED I (\%) & ED II $(\%)$ \\
\hline None/No problems & 19.00 & 20.85 \\
\hline $\begin{array}{l}\text { I could not access information } \\
\text { on universities and programs }\end{array}$ & 14.25 & 10.29 \\
\hline $\begin{array}{l}\text { I had difficulty in paying for } \\
\text { the expenses related to higher } \\
\text { education }\end{array}$ & 24.80 & 28.74 \\
\hline $\begin{array}{l}\text { I had difficulty preparing } \\
\text { application and registration } \\
\text { documents }\end{array}$ & 15.04 & 14.43 \\
\hline $\begin{array}{l}\text { I had difficulty because of the } \\
\text { language problem }\end{array}$ & 18.85 & 11.61 \\
\hline Other & 10.82 & 15.30 \\
\hline
\end{tabular}

Source ED I and ED II questionnaire

but also compares them across the two waves of the ED Project. According to their answers, only $20 \%$ of the students in our sample have not experienced any difficulties accessing education, which is almost the same with the ED-I findings, whereas $29 \%$ had problems meeting the costs associated with higher education, $19 \%$ faced issues due to the language barrier, $14 \%$ in securing documentation required for application or admission, and $10 \%$ had issues accessing information regarding different universities and their programs. This result points to the need and importance of scholarships, as the rate increased from $24.80 \%$ in the ED-I. Having difficulty with language, on the other hand, decreased in the ED-II, which is a positive sign both for the integration into society and also the academic success of the students. Accordingly, for both waves, the financial costs still constitute the most important challenge regarding access, followed by obtaining required registration documents as well as language barriers. The information deficit seems to have lessened, but other problems, such as the financial needs, persist (Table 2).

In the ED-II, a new question was added to the survey in order to ask about the difficulties faced after the students started their studies. Difficulties with learning Turkish appear to be the highest ranked one since 38\% of Syrian students stated this. Considering that this is an obstacle for both the academic and social adaptation of the students to their new environment, it is no surprise that it comes out as the most important challenge for Syrian students where they need assistance. This challenge is followed by grades, the registration process, and course comprehension. Areas where the students faced the least amount of challenges are administrative staff, academic faculty members, and fellow students, which demonstrates that students have comparatively low challenges with their social environment despite the language problem. The top four difficulties are directly related to their inability to learn academic Turkish, and it affects their comprehension of the courses, their exam grades, and their communication and problem-solving abilities (Figs. 6, 7 and 8). 
Fig. 6 Study fields of the participating students Source ED I and ED II questionnaire

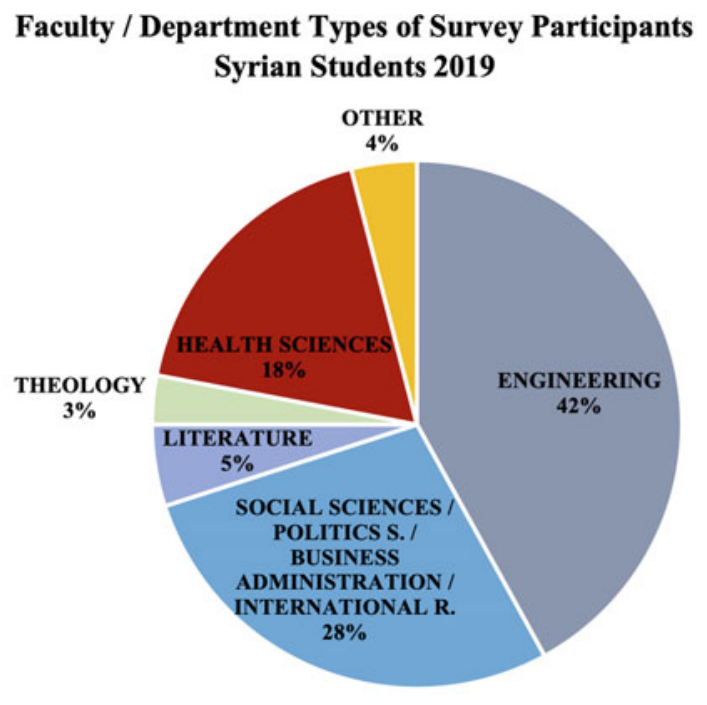

Faculty / Department Types of Survey Participants
Syrian Students 2017

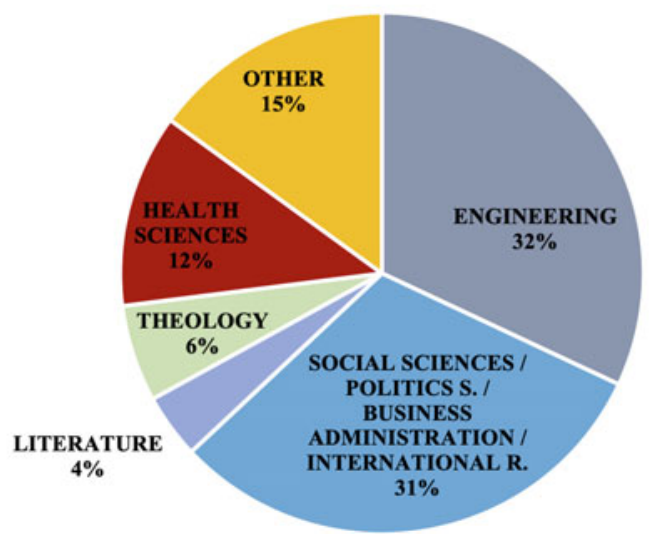

A module on students' satisfaction with various aspects of life and education at their respective institutions has been incorporated into the ED-II student survey. The results regarding their perceptions of their universities are displayed in the following graph, where 1 indicates no satisfaction and 5 indicates high satisfaction. Accordingly, students are most satisfied with the infrastructure of their universities, the quality of education in their respective departments, and the support they receive from academic advisors. While still above average in terms of overall satisfaction, the students seem to be less happy about the accommodation conditions, the course 


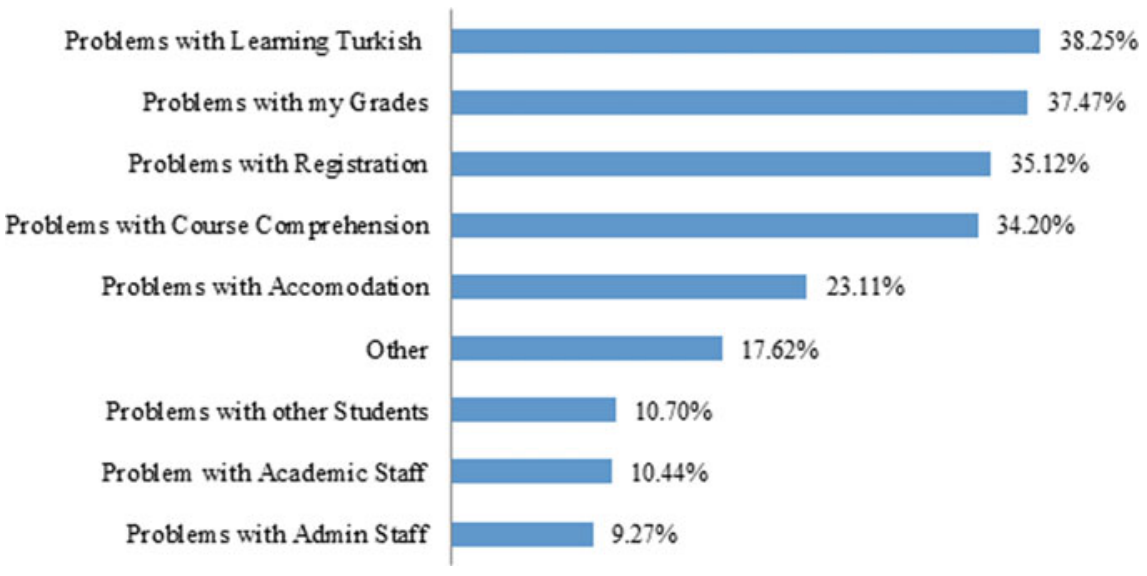

Fig. 7 Problems faced during studies Source ED II questionnaire

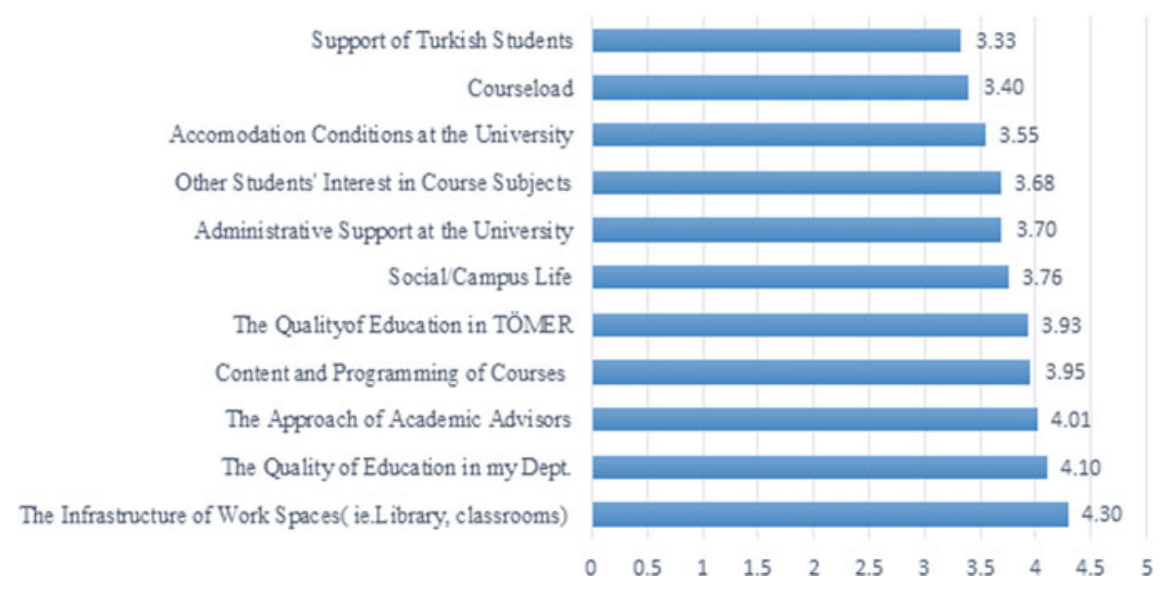

Fig. 8 Satisfaction with various aspects of life and education Source ED II questionnaire

load per semester, and the level of support they get from fellow Turkish students. When we crosscheck these results with the ones in the other questions, we can estimate that since they have to work in order to earn their living and since they have insufficient language proficiency, the course load becomes heavier for them.

Another indicator that they selected as the lowest in their list is support by the Turkish students. This indicator is tested in another question where Syrian students were asked about their relations with the local students. About 405 indicated they have good relations while a remarkable $33 \%$ identified their relations as either poor or medium. When we compare the findings of the ED-I and II, it seems that relations have improved in two years. This finding is a good indicator of social cohesion and indicates that there is more and better inter-group contact from the perspective of 
Table 3 Relations with Turkish students at the university

\begin{tabular}{l|l|l}
\hline Options & ED I (\%) & ED II $(\%)$ \\
\hline Poor & 19.79 & 9.50 \\
\hline Average & 20.32 & 23.74 \\
\hline Above average & 8.97 & 15.08 \\
\hline Good & 24.54 & 33.80 \\
\hline Very good & 26.39 & 17.88 \\
\hline
\end{tabular}

Source ED II questionnaire

Syrian students. However, strikingly, the poor and very good relations have decreased in the second research sample. It can be evaluated that the more students get to know each other, the more they have realistic perceptions rather than exaggerations as time passes (Table 3).

Financial matters are one of the most controversial issues for Syrian university students in Turkey. Unlike other international students, Syrians are exempt from all tuition fees in state universities in Turkey, and this creates discontentedness in the general public. The high number of scholarships offered to students in higher education through governmental and international agencies is pointed out as an example of good practice in Turkey and is internationally acclaimed. The central part of these grants distributed by the YTB is provided by the Prime Ministry funds, some from European Union funds, and some from the DAFI funds managed by the UNHCR; and, the number of scholarships granted is increasing. Additionally, international organizations, such as SPARK, facilitate Syrian students' access to higher education through scholarships granted under similar conditions in line with similar criteria. When asked about their source of income as an indicator of their economic wellbeing, more than $56 \%$ of students indicated that they are supported by their families. A very high percentage of the students -about $40 \%$-indicated that they work full time or part time to support their studies, whereas only $11 \%$ stated that they get scholarships. Comparing these results with the ED-I, there is a significant difference. In the first wave of the research, the students who stated that they work was about $25 \%$, and the scholarship percentage was 18\% (Erdogan and Erdogan 2018). This result indicates that the number of students who work to support their studies has doubled. Moreover, the rate of those receiving scholarships has decreased dramatically. This decrease is due to the increasing number of students and indicates that more funds are needed for the future. However, despite all of these scholarships, the number of students receiving scholarships is deficient, and as determined in our research, increasing the scholarships is a critical need for them to continue their education. In our opinion, the absolute number of recipients may not have dropped, but as the number of university students has increased, their percentage may have decreased. Between the two waves, a considerable number of university students became Turkish citizens, which makes them no longer eligible for these scholarships. This finding is reflective on the income sources pattern in that more students work now as compared to the first wave of the survey to support themselves (Fig. 9). 
Fig. 9 How do you support your studies?

Source ED II questionnaire

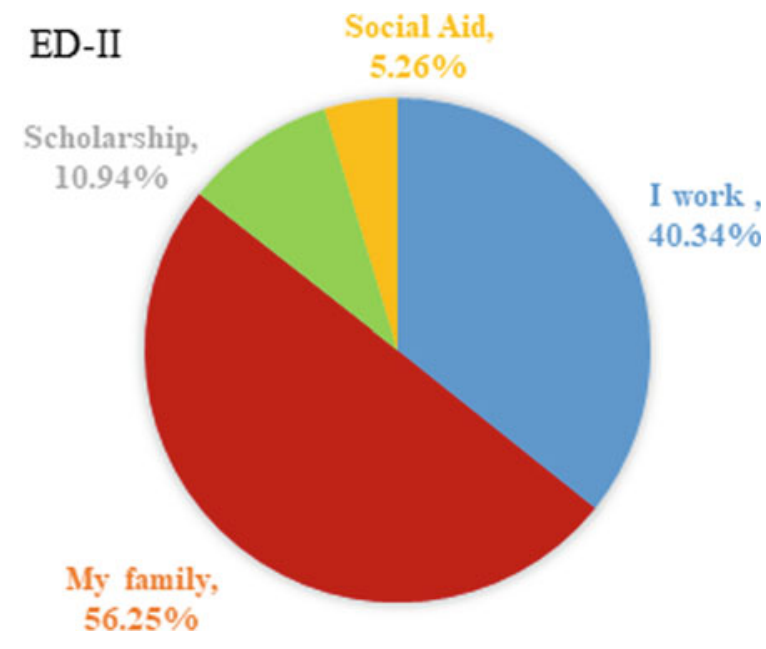

There are various sources of vulnerabilities that can have an impact on students' education and social integration. ED-I attests to the fact that Syrian university students suffer from various sources of trauma, therefore ED-II aimed to further explore this issue. To this end, an index has been constructed, compiling various sources of trauma inflicting events. In preparing this index, similar indices implemented in other contexts have been considered, and then students were asked about their experiences with these different kinds of trauma. The striking results are illustrated in the belowmentioned table. Accordingly, more than half of the students have experienced fear, loss of a friend or relative, interruption with schooling, rapid impoverishment, having to stop studies and having to work, forced relocation, dissolvement of the family, and direct psychological trauma. In order to have an idea about the substance of this trauma, we asked them about their losses in the war. Only $13.8 \%$ of our respondents have not lost someone they know during the civil war in Syria, while $60 \%$ lost a distant or close relative, and $25 \%$ lost a friend. Multiple responses were allowed for the aforementioned trauma index, and it became apparent that many students have experienced multiple trauma inflicting situations.

When asked about their future perspectives like their intentions to return to Syria, a much-debated issue both nationally and internationally, 34\% of students indicated that they have no intention to return to Syria, whereas only $6 \%$ indicated high interest in returning even if the war continues. Another $6 \%$ is interested in returning even if their desired regime is not established in Syria. Nevertheless, a bulk of the respondents, 55\%, indicated that they would return only if their desired regime is established, which is a rather difficult task to meet for every refugee. This finding alludes to the need for future plans for the Syrian students not only in Turkey but also in the EHEA since according to another survey question, they tend to have further studies in Europe (Table 4). 
Table 4 Trauma experiences

\begin{tabular}{l|l|l}
\hline Experiences & Number & Percentage (\%) \\
\hline Forced relocation & 585 & 77.28 \\
\hline Rapid impoverishment & 549 & 72.52 \\
\hline Education interruption & 533 & 70.41 \\
\hline Direct psychological trauma & 476 & 62.88 \\
\hline Fear & 470 & 62.09 \\
\hline Dissolvement of family & 438 & 57.86 \\
\hline Loss of a relative & 404 & 53.37 \\
\hline Loss of a friend & 396 & 52.31 \\
\hline Having to work & 367 & 48.48 \\
\hline Loss of a known person & 358 & 47.29 \\
\hline Permanent physical disability & 38 & 5.02 \\
\hline Total & 757 & \\
\hline
\end{tabular}

\section{Concluding Remarks and Recommendations}

Since 2011, millions of Syrian people have had to leave their country and seek shelter in neighbouring countries and in Europe. Forced migration or displacement creates multiple vulnerabilities while trying to settle in a new environment. Socioeconomic, cultural, and psychological vulnerabilities hinder them from participating actively in society. Higher education is one of the main ways that refugees and displaced people cling to hope for a better life. Their access to and participation in higher education has been a challenging route for many reasons both for themselves and also for the higher education systems and universities in their host countries.

Turkey has a unique place in regard to Syrian refugees. It hosts the largest refugee population in the world with 3.6 million Syrians and 500,000 asylum seekers from other countries, such as Iraq, Iran, Afghanistan, and Pakistan. Turkey has a young population with the 5-17 age group comprising $21 \%$ of the population, but the Syrian population is much younger as its rate is $30 \%$. Turkey is also the country with the largest student population in the European Higher Education Area. The incomparable magnitude of the situation, among others, plays a crucial role in developing new integration policies. In spite of the ongoing difficulties and challenges, the past nine years proved a success story in protection, social-cohesion, and integration of these newcomers.

Turkey has been suffering from some challenges, such as a supply and demand imbalance in higher education. Demographic factors, shortcomings of the higher education system, and the unemployment rate among university graduates have been some long-term challenges for Turkish higher education. Moreover, a common misconception in public opinion, that Syrian refugees are admitted to Turkish universities without fulfilling the requirements, adds new challenges for future policies. Both the 
sheer number of migrants and also the emergency of the situation during this migration flow necessitated some action to be taken in the area of higher education. In a country like Turkey, where there is high competition between students to pass the nationwide university selection exam each year, encouraging Syrian students to access higher education, seems to be an area for discussion.

This paper is based on the fieldwork of research conducted in the context of the Hopes-MADAD project entitled "Elite Dialogue II- Dialogue with Syrian Refugees in Turkey through Syrian Academics and Students" in 2019 and the previous phase of the project, Elite Dialogue II. The main research subject is which types of vulnerabilities Syrian university students face, and how they can integrate into society in Turkey. Research on the higher education practices of vulnerable groups in general, and of Syrian students in particular, is largely missing in Turkey, while the international research and literature is rather Eurocentric and does not represent the vast scale of Turkish experience.

The number of Syrians living in Turkey has exceeded 3.6 million, thus the main argument of the research team was that a large portion of this population would remain in Turkey. Moreover, the education level of Syrians living in Turkey is very low compared to both Turkish society and to the Syrians who moved to Europe. Therefore, it is important that university students and academics help with developing new policies, establish healthy communication with the Syrian community as a whole, and play a bridge role in the adaptation process in the host country. "Elite" Syrian groups are vital for future integration policies as "role models," "pioneers," and "bridges." They might also be role models for their community and good examples for the host community to develop positive communication channels.

The number of Syrian students who are studying at 153 public and foundation universities in Turkey exceeded 27,034 in 2019. Half of these Syrian students are those who had to interrupt their education and come to Turkey, and the other half consists of high school graduates who passed the university entrance exam for international students (YÖS) and other exams successfully and now attend university. Syrian university students represent the largest group among the 148,000 international students in Turkey (CoHE 2019). This is undoubtedly an important achievement and investment both for the Syrian community and for Turkey. On the other hand, since accessing higher education for Turkish citizens is a very competitive process, Syrian university students in Turkey are often the centre of public opinion discussion topics.

Although ED research focused on Syrian students in Turkey, after analysing the data, we have the following observations and recommendations to define the problem areas and challenges and to suggest possible solutions for the future in Turkey and in the EHEA since the topics and challenges have indispensable commonalities. Moreover, it will be a timely recommendation for the EHEA, which is wider than the EU, to state that perspectives of non-EU countries should be taken into account to achieve more inclusive regional higher education area.

Our findings indicate that the immense influx of Syrian refugees compelled a number of immediate actions in Turkish higher education as well as in other services. Thus, Turkey is not only the country hosting the largest refugee population but is also facilitating the biggest refugee student rate $(5 \%)$ in higher education in the world. 
Both the government and citizens are carrying the burden of accepting and hosting 4.2 million refugees. For a country, whose demographic and economic indicators are already challenging, integrating more than 27 thousand students into higher education is a great success. Nevertheless, the needs and challenges faced by the local people were complicated and have dramatically increased since the influx started in 2011. The social dimension for Turkish university students seems to be neglected due to the immediate needs and vulnerabilities of the refugee population. This creates hot debates in public (Erdogan 2018a).

The main difficulties Syrian students face in accessing and continuing higher education seem to be language insufficiency, financial deficiency, and multiple vulnerabilities. Academic and financial support for language learning is required for their academic success, for their career development, and also to integrate into society. A clear, rapid impoverishment is reported by the students after the war started in Syria, after they fled their country, and at present. Therefore, more than half have to work to continue their studies. Only $11 \%$ of the respondents stated that they receive any scholarships, which is compatible with the actual numbers. Efforts should be made to provide, diversify, and increase scholarships for Syrian students from international sources. Different from regular international students, refugee populations have experienced various traumas during this process and are in need of psychological counselling.

All difficulties intermingle with each other and affect future perspectives. Both in our research and also in the actual conditions, employability remains a big challenge for the future. Considering that Turkey has a youth unemployment rate of more than $25 \%$, this rate will be bigger for the Syrian refugees after their graduation. It is highly likely that young Syrians will go to other countries if they cannot find jobs in Turkey after they graduate.

Representation and participation of Syrian students in decision-making processes seem to be lacking in practice. For the efficiency and sustainability of the policies and reforms, their voices need to be heard for future policies. It is important to collect reliable, updated, and detailed data about the Syrian students to develop new policies. Moreover, a reliable communication strategy is needed to inform both Turkish society and the international community correctly and simultaneously. This may help diminish the misunderstandings or negative approach of the public towards the Syrian community in Turkey and may help a more positive integration process starting from the higher education students.

Research shows that the tendency of Syrians in Turkey to stay permanently increases each day (Erdogan 2018b). Turkey applied a very positive approach accepting and responding to the large influx of Syrians. Despite the legislative limitations, as Syrians are not refugees but under temporary protection status according to Turkey's geographical limitation put in the Geneva Convention in 1951, inclusive policies allowed Syrians to benefit from facilities in health, education, and socioeconomical public services. Higher education is facing new challenges due to the changing social dynamics of Europe and around the globe. Higher education is a significant indicator of integration for newcomers. ED Projects, based on this view, argue that Syrian academics and students will play an important role in establishing positive 
communication between the refugees and the host country. Through the experiences of Turkey in the last nine years since the Syrian refugee crisis began, findings of the ED projects may contribute to more inclusive policies and comprehensive outreach and in the EHEA for the forthcoming decade. To go beyond the previous Ministerial Communiqués, clear statements, concrete measurements, decisive implementations, and sustainable policies are necessary for the new decade to include the new vulnerable groups in addition to the existing under-represented groups.

\section{References}

Bloch, A., \& Dona, G. (Eds.). (2019). Forced Migration: Current Issues and Debates, Routledge (e-book) (retrieval date 11.01.2020).

CoHE (2014). Executive Board Decision. https://www.yok.gov.tr/ogrenci/ek-madde-2-uyarincamisir-ve-suriyeden-yapilabilecek-yatay-gecis-islemlerine-iliskin-esaslar Retrieval Date: 12.03.2020.

CoHE (2019). International Student Statistics, https://istatistik.yok.gov.tr/ (Retrieval Date: 12.02.2020).

Council of Europe (2019). European Qualifications Passport for Refugees https://www.coe.int/en/ web/education/recognition-of-refugees-qualifications Retrieval Date: 05.02.2020.

Cremonini, L. (2016, March 11). Higher education has a key role in integrating refugees. University World News. http://www.universityworldnews.com/article.php?story=20160311205508924 (Retrieval Date: 12.08.2019).

de Wit, Hans \& Altbach, Philip G. (2016). The Syrian Refugee Crisis and Higher Education, International Higher Education, (84), 9-10.

Directorate General of Migration Management (DGMM) (2020). Distribution of Syrians under Temporary Protection by Years https://en.goc.gov.tr/temporary-protection27 (Retrieval Date 19.03.2020).

EHEA (2007). London Communiqué. http://www.ehea.info/Upload/document/ministerial_ declarations/2007_London_Communique_English_588697.pdf Retrieval Date 19.03.2020.

EHEA (2015). Yerevan Communiqué. http://ehea.info/media.ehea.info/file/2015_Yerevan/70/7/ YerevanCommuniqueFinal_613707.pdf Retrieval Date: 05.02.2020.

EHEA (2018). Paris Communiqué. http://ehea.info/Upload/document/ministerial_declarations/ EHEAParis2018_Communique_final_952771.pdf Retrieval Date: 05.02.2020.

Erdogan A., \& Erdogan M. M. (2018). Access, Qualifications and Social Dimension of Syrian Refugee Students in Turkish Higher Education. In A. Curaj, L. Deca, \& R. Pricopie (Eds.), The European Higher Education Area: The Impact of Past and Future Policies, https://www.springer. com/us/book/9783319774060\#aboutBook.

Erdogan, M. M., (2018a). Türkiye'deki Suriyeliler: Toplumsal Kabul ve Uyum (Syrians in Turkey: Social Acceptance and Integration) ( $2^{\text {nd }}$ ed) Bilgi Yayınevi: Istanbul.

Erdogan, M.M., (2018b). Suriyeliler Barometresi: Suriyelilerle Uyum İçinde Yaşamın Çerçevesi (Syrians Barometer: A framework for achieving social cohesion with Syrians in Turkey) İstanbul Bilgi Üniversitesi Yayınevi.

Erdogan, M.M., \& Erdogan A., (2019). Elite Dialogue II-Dialogue with Syrian Refugees in Turkey through Syrian Academics and Students Project Report.

European Commission/EACEA/Eurydice (2019). Integrating Asylum Seekers and Refugees into Higher Education in Europe: National Policies and Measures. Eurydice Report. Luxembourg: Publications Office of the European Union.

Habertürk Newspaper. (2014, September, 26). Special Status for Students who are victims of war, https://www.haberturk.com/gundem/haber/993931-savas-magduru-ogrencilere-ozel-statu 
International Organization for Migration (IOM) (2020). World Migration Report 2020, https:// publications.iom.int/system/files/pdf/wmr_2020.pdf (Retrieval Date: 05.02.2020).

Jungblut, J., \& Pietkiewicz, K. (Eds.). (2017). Refugees Welcome? Recognition of qualifications held by refugees and their access to higher education in Europe-country analyses, European Students' Union: Brussels.

Kirişci, Kemal (2014). Syrian Refugees and Turkey's Challenges: Going Beyond Hospitality. The Brookings Institution, Washington DC.

Milliyet Newspaper. (2015, January, 10). Programs can be opened for Syrian students in Arabic. https://www.milliyet.com.tr/gundem/suriyeliler-icin-arapca-bolumler-acilabilecek-1996582.

Ministry of Development (March 2015). Needs Assessment of Syrian Women and Girls Under Temporary Protection Status in Turkey http://www.kalkinma.gov.tr (Retrieval Date: 05.07.2016).

Ministry of National Education, Directorate General Life Long Learning Report (2020). https:// hbogm.meb.gov.tr/meb_iys_dosyalar/2020_01/27110237_OCAK_2020internet_BulteniSunu. pdf Retrieval Date: 05.02.2020.

Official Gazette (2014). Decision of the Council of Ministers about "Determination of Contribution Fees to be Received as Student Contributions to Current Service Costs in Higher Education Institutions in 2014-2015 Academic Year. 27 September 2014 (Retrieval Date: 05.02.2020).

Piguet, E. (2018). Theories of voluntary and forced migration. In R. McLeman \& F. Gemenne (Eds.), Routledge Handbook of Environmental Displacement and Migration. Routledge: NY.

Stevenson, J., \& Baker, S. (2018). Refugees in Higher Education: Debate, Discourse and Practice, Emerald Publishing Limited: London.

Streitwieser, B., Miller-Idriss, C., \& de Wit, H. (2016). Higher Education's Response to the European Refugee Crisis: Challenges, Strategies, and Opportunities, Working Paper, The George Washington University: Washington DC. https://gsehd.gwu.edu/sites/default/files/documents/ bernhard_streitwieser_working_paper_10.2016_final.pdf (Retrieval Date: 01.08.2019).

UN (1948). Universal Declaration of Human Rights https://www.un.org/en/universal-declarationhuman-rights/ Retrieval Date: 05.02.2020.

UN (2015). Sustainable Goals and Targets https://www.un.org/development/desa/disabilities/ envision2030-goal4.html Retrieval Date: 11.01.2020.

UN (2016). New York Declaration for Refugees and Migrants https://www.un.org/en/ga/search/ view_doc.asp?symbol=A/RES/71/1 Retrieval Date: 05. 02. 2020.

UNESCO (2017). Migration and Education, Think piece prepared for the 2019 Global Education Monitoring Report Consultation, https://es.unesco.org/gem-report/sites/gem-report/ files/Think\%20piece\%20-\%20International\%20migration\%20and\%20education\%20-\%20Tani \%20-\%20FINAL.pdf Retrieval Date: 11.01.2020.

UNHCR (1951). Convention Relating to the Status of Refugees https://www.unhcr.org/5d9ed32b4 (Retrieval Date: 03.12.2019).

UNHCR (2018). Global Compact on Refugees. https://www.unher.org/the-global-compact-onrefugees.html (Retrieval Date: 05.01.2020).

UNHCR (2019a). Figures at a glance. https://www.unhcr.org/figures-at-a-glance.html (Retrieval Date: 05.12.2019).

UNHCR (2019b). Tertiary Education. https://www.unhcr.org/tertiary-education.html (Retrieval Date: 05.02.2020).

UNHCR (2019c). Global Framework for Refugee Education. https://www.unhcr.org/5dd50ce47. pdf (Retrieval Date: 05.01.2020).

Yidız, Ayselin (Ed.) (2019). Integration of Refugee Students in European Higher Education: Comparative Country Cases. Izmir: Yasar University Publications.

Zgaga, P. (2015). The social dimension in the European Higher Education Area. In B. Baranović (Ed.), Koji srednješkolci namjeravaju studirati? Pristup visokom obrazovanju i odabir studija [Which high school students plan to study? Access to higher education and the selection of studies], (pp. 211-233). (Biblioteka Znanost i društvo, 37). Zagreb: Institut za društvena istraživanja. 
Open Access This chapter is licensed under the terms of the Creative Commons Attribution 4.0 International License (http://creativecommons.org/licenses/by/4.0/), which permits use, sharing, adaptation, distribution and reproduction in any medium or format, as long as you give appropriate credit to the original author(s) and the source, provide a link to the Creative Commons license and indicate if changes were made.

The images or other third party material in this chapter are included in the chapter's Creative Commons license, unless indicated otherwise in a credit line to the material. If material is not included in the chapter's Creative Commons license and your intended use is not permitted by statutory regulation or exceeds the permitted use, you will need to obtain permission directly from the copyright holder. 